\title{
Françoise Dieterlen (1932-2021)
}

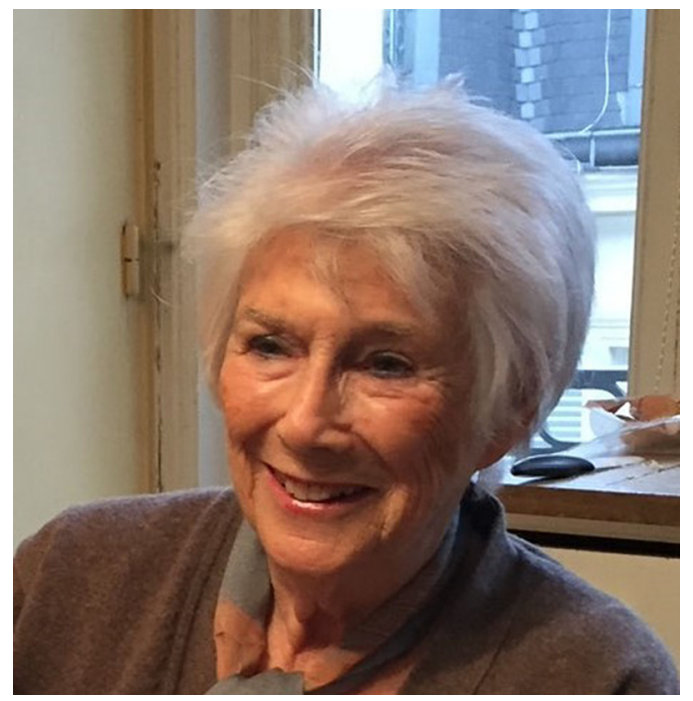

C'est avec une grande tristesse que le Bureau, le Conseil et tous les membres de la Société de Biologie ont appris le décès, le 13 juillet à Nîmes, de Françoise Dieterlen. La Société dont elle a été la première Présidente (2008-2012), après en avoir été la Secrétaire Générale et, pendant vingt ans, la rédactrice en chef du Journal, lui rendra hommage lors d'une journée scientifique, organisée conjointement avec le CNRS pour honorer la mémoire d'une grande dame de la recherche en Biologie.

André Calas 